А. М. ФІЛІПСЬКА ${ }^{1}$ (https://orcid.org/0000-0002-5759-1521), здобувач,

I. О. ВЛАСЕНКО ${ }^{2}$ (https://orcid.org/0000-0002-5530-4189), канд. фарм. наук, доцент, здобувач, Н. І. ГУДЗЬ ${ }^{1}$ (https://orcid.org/0000-0002-2240-0852), д-р фарм. наук, доцент

${ }^{1}$ Львівський національний медичний університет імені Данила Галиџького

${ }^{2}$ Національний університет охорони здоров'я Украйни імені П. Л. Шупика, м. Київ

АСПЕКТИ ПРОМИСЛОВОГО ВИРОБНИЦТВА КОНЦЕНТРАТІВ ДЛЯ

ГЕМОДІАЛІЗУ

Ключові слова: кислотні концентрати для гемодіалізу, промислове виробництво, екологічні ризики, фармацевтичні відходи

A. M. FILIPSKA ${ }^{1}$ (https://orcid.org/0000-0002-5759-1521),

I. O. VLASENKO ${ }^{2}$ (https://orcid.org/0000-0002-5530-4189),

N. I. HUDZ ${ }^{1}$ (https://orcid.org/0000-0002-2240-0852)

\title{
ASPECTS OF THE INDUSTRIAL MANUFACTURE OF CONCENTRATES FOR HAEMODIALYSIS
}

${ }^{1}$ Danylo Halytsky Lviv National Medical University

${ }^{2}$ Shupyk National Healthcare University of Ukraine

Key words: acid concentrates for hemodialysis, industrial manufacture, environmental risks, pharmaceutical wastes

Проблема хронічної хвороби нирок (XXН) із медичної, соціальної та організаційної точок зору зумовлена високою летальністю, інвалідизацією пацієнтів і складністю технічного забезпечення сучасними методами лікування пацієнтів із цією патологією. На пізніх стадіях ХХН застосовують замісну ниркову терапію, основною різновидністю якої є гемодіаліз (ГД), унаслідок якого відбувається видалення з організму токсичних продуктів обміну речовин і нормалізація порушень водного й електролітного балансів [1].

Для ГД використовують багатокомпонентні розчини, склад яких близький до складу плазми крові людини. Оскільки розчини для Гд використовують у значних об’ ємах, їх зазвичай виробляють у формі кислотних концентратів, які безпосередньо перед процедурою ГД розводять водою спеціальної очистки з подальшим додаванням 8,4\%-го розчину натрію гідрокарбонату [2].

Фармацевтичний ринок України концентратів для ГД в основному є імпортозалежним [3], тому їх виробництво є актуальним завданням сучасної фармацевтичної науки.

Розробленню промислової технології рідких кислотних концентратів для ГД передує ретельне опрацювання технології лабораторних і дослідно-промислових серій. Це дає змогу зібрати достатню кількість теоретичних та експериментальних даних щодо обгрунтування підготовки сировини, послідовності введення компонентів на стадії приготування концентрату, підбору умов розчинення активних речовин, перемішування й фільтрування концентрату, а отже, детальніше спрогнозувати виробничий процес і його критичні точки й показники, опрацювати технологічну документацію для дослідно-промислових і промислових серій тощо.

Опрацювання трансферу в промислове виробництво і відповідно розроблення промислової технології рідких кислотних концентратів передбачає масштабування технологічного процесу, організацію міжопераційного контролю, встановлення критичних точок технологічного процесу, а також визначення класів чистоти приміщень для виробництва концентратів і ризиків, у тому числі екологічних.

(с) Колектив авторів, 2021 
ГД здійснюють за допомогою апаратів (діалізаторів) із використанням діалізного розчину, що містить електроліти $\mathrm{i}$, як правило, активну речовину з буферними властивостями, а інколи додатково глюкозу. Цей розчин призначений для обміну речовинами з кров'ю під час ГД [2]. Бікарбонатний діалізний розчин одержують із концентрату кислотного, води очищеної і натрію гідрокарбонату. Кислотний (кислотовмісний) концентрат (acid concentrate) або А-концентрат (A-concentrate) - підкислена концентрована суміш солей, яка після розведення водою для діалізу й додавання бікарбонатного концентрату формує діалізний розчин для ГД. Кислотні концентрати вміщують натрію хлорид, калію хлорид, кальцію хлорид і магнію хлорид. Для створення необхідного значення рН концентрату зазвичай додають оцтову кислоту [4].

Метою цієї роботи є опрацювання підходів до розроблення технології промислового виробництва кислотних концентратів, визначення ризиків у технологічному процесі й контролі якості, а також аналіз головних екологічних ризиків і розроблення методів їх зниження.

\section{М ат е р і али т а методи дослідження}

Об'єктом дослідження була нормативно-технічна документація стосовно вимог до концентратів для ГД, характеристика профілю небезпеки кислотних концентратів як джерела фармацевтичних відходів (ФВ) і узагальнення інформації про ФВ виробництва кислотних концентратів. Використовували результати власних експериментальних досліджень щодо розроблення концентратів, склад яких наведено в табл. 1 [5].

Т а б ли ц я 1

Склад досліджуваних концентратів

\begin{tabular}{|l|c|c|}
\hline \multirow{2}{*}{ Компонент } & \multicolumn{2}{|c|}{ Концентрація, ммоль/л } \\
\cline { 2 - 3 } & Склад 1 & Склад 2 \\
\hline $\mathrm{Na}^{+}$ & 3605,0 & 3605,0 \\
\hline $\mathrm{K}^{+}$ & 70,0 & 70,0 \\
\hline $\mathrm{Mg}^{2+}$ & 17,5 & 17,5 \\
\hline $\mathrm{Ca}^{2+}$ & 52,5 & 43,8 \\
\hline $\mathrm{CH}_{3} \mathrm{COO}^{-}$ & 105,0 & 105,0 \\
\hline $\mathrm{Cl}^{-}$ & 3815,0 & 3797,6 \\
\hline Глюкоза & - & 194,4 \\
\hline Вода очищена & \multicolumn{2}{|c|}{ до 1 л } \\
\hline
\end{tabular}

Для аналізу нормативно-технічної документації застосовували системно-оглядовий метод дослідження й контент-аналіз.

\section{Результати дослідження та обговорення}

Для промислового виробництва усі складові (виробничі приміщення відповідних класів чистоти, обладнання, якість води, активних речовин тощо) необхідно підбирати з урахуванням головної особливості кислотних концентратів для ГД - великих об'ємів використання: за один сеанс для пацієнта використовують близько 150 л діалізної рідини, що відповідає 5 л кислотного концентрату, за тиждень - до 600 л, а за рік - 18-36 тис. л [6-8].

На нашу думку, концентрати для ГД можна віднести до граничної категорії фармацевтичних продуктів, яка знаходиться між стерильними і нестерильними продуктами. Це твердження передусім базується на положеннях монографії Європейської 
фармакопеї стосовно мікробіологічної чистоти концентратів: або стерильні, або повинні мати якомога нижчий рівень мікробіологічного забруднення [2]. Також концентрати ми розглядаємо як проміжну категорію між лікарськими засобами (ЛЗ) і медичними виробами. Як ЛЗ концентрати після відповідного розведення контактують із кров'ю пацієнта через напівпроникну мембрану.

Значна кількість бактерій у гемодіалізному розчині створює ризик бактеріємії або ендотоксемії для пацієнтів на ГД у зв'язку з можливим проходженням бактеріальних ендотоксинів через мембрану або через трансмембранну стимуляцію макрофагів і подальшу продукцію цитокінів, спровоковану ендотоксином або бактеріями [6]. Вищі концентрації бактеріальних ендотоксинів можуть спричинити пірогенну реакцію. За низького рівня пірогени стимулюють вивільнення прозапальних цитокінів із моноцитів. Видалення бактеріальних продуктів із діалізного розчину зменшить навантаження на систему імунного захисту пацієнта. Межу вмісту ендотоксинів було визнано істотним критерієм якості води і діалізного розчину. Цю межу було визначено в ISO 23500-5:2019 «Preparation and quality management of fluids for haemodialysis and related therapies - Part 5: Quality of dialysis fluid for haemodialysis and related therapies», оскільки кінцевий діалізний розчин має найбільший вплив на пацієнта і є комбінацією багатьох чинників, таких як мікробіологічна чистота концентрату, води і чистоти апаратів для діалізу й будь-яких відповідних систем розподілу $[4,8]$.

Незважаючи на те, що частота виявлення підвищеного рівня алюмінію в багатьох діалізних установах надзвичайно низька і суттєво знизилася, зокрема завдяки удосконаленню технологій очищення води, інтоксикація алюмінієм продовжує залишатися клінічним занепокоєнням, оскільки така інтоксикація може призвести до серйозних захворювань [9]. Також дослідження показують, що високий рівень алюмінію в сироватці пацієнтів на ГД є однією з головних причин смерті [10].

Тому для виготовлення концентратів необхідно використовувати активні і допоміжні речовини фармакопейної якості, які додатково контролюють передусім за вмістом алюмінію, а також із відповідним показником «мікробіологічна чистота» $[4,11]$. Критерії прийнятності для нестерильних субстанцій для фармацевтичного застосування базуються на загальному числі аеробних мікроорганізмів (TAMC) і загальному числі дріжджових та плісеневих грибів (ТYМС) і становлять $10^{2}$ та $10^{3} \mathrm{KУO/г} \mathrm{відпо-}$ відно [11].

Достатньо жорсткі вимоги до якості води мають бути дотримані, щоб забезпечити впевненість у тому, що вода, яку використовують для підготовки концентратів, не вноситиме суттєвого додаткового внеску до рівня хімічного забруднення концентратів [4].

У настанові «Лікарські засоби. Якість води для застосування у фармації СТ-Н МОЗУ 42-3.7:2013» і Державній фармакопеї України (ДФУ) наведено показники якості, які необхідно контролювати для випадків, коли активні речовини призначено для виробництва розчинів для діалізу $[12,13]$. Не вказано, який вид діалізу (перитонеальний діаліз, ГД, гемофільтрація чи гемодіафільтрація), хоча вони мають принципову відмінність у медичному застосуванні: розчини для ПД є стерильними, які вводять інтраперитонеально, розчини для гемофільтрації і гемодіафільтрації вводять внутрішньовенно, а розчини для ГД контактують із кров’ю пацієнта через напівпроникну мембрану.

У табл. 2 подано узагальнену інформацію щодо критичних показників якості для води різних категорій, які необхідно враховувати під час підготовки води, що буде використана як розчинник в остаточній рецептурі рідких концентратів для ГД $[2,8$, $12-14]$. 
Т а бли ц я 2

Вимоги до води різної якості й призначення

\begin{tabular}{|c|c|c|c|c|c|}
\hline \multicolumn{6}{|c|}{ Нормативні документи } \\
\hline & $\begin{array}{l}\text { Монографія } \\
\text { ДФУ «Вода очищена» } \\
\text { (вода очищена in bulk) }\end{array}$ & $\begin{array}{l}\text { Монографія } \\
\text { ДФУ «Вода високоо- } \\
\text { чищена» }\end{array}$ & $\begin{array}{l}\text { Монографія } \\
\text { ДФУ «Вода для } \\
\text { ін'єкцій» (вода для } \\
\text { ін'єкцій in bulk) }\end{array}$ & \begin{tabular}{|l} 
Монографія \\
ЄФ «Вода для роз- \\
ведення концен- \\
тратів для ГД» \\
\end{tabular} & $\begin{array}{l}\text { ISO 23500- } \\
3: 2019\end{array}$ \\
\hline \multicolumn{6}{|c|}{ Способи одержання води } \\
\hline & $\begin{array}{l}3 \text { води питної дис- } \\
\text { тиляцією, іонним } \\
\text { обміном, зворотним } \\
\text { осмосом або будь- } \\
\text { яким іншим підхожим } \\
\text { способом }\end{array}$ & $\begin{array}{l}3 \text { води питної методом } \\
\text { подвійного зворот- } \\
\text { ного осмосу спільно } \\
3 \text { іншими підхожими } \\
\text { методами, наприклад, } \\
\text { ультрафільтрацією і } \\
\text { деіонізацією }\end{array}$ & $\begin{array}{l}3 \text { води питної або } \\
\text { iз води очищеної } \\
\text { шляхом дистиляції }\end{array}$ & $\begin{array}{l}3 \text { води питної } \\
\text { дистиляцією, зво- } \\
\text { ротним осмосом, } \\
\text { іонним обміном, } \\
\text { або будь-яким } \\
\text { іншим підхожим } \\
\text { способом }\end{array}$ & $\begin{array}{l}\text { Нанофільтра- } \\
\text { ція, зворот- } \\
\text { ний осмос, } \\
\text { абсорбція } \\
\text { активований } \\
\text { вугіллям }\end{array}$ \\
\hline \multicolumn{6}{|c|}{ Показники якості води } \\
\hline $\begin{array}{l}\text { Вміст ендоток- } \\
\text { синів }\end{array}$ & $\begin{array}{l}<0,25 \text { МО/мл, якщо } \\
\text { без подальшої про- } \\
\text { цедури видалення } \\
\text { бактеріальних ендо- } \\
\text { токсинів } \\
\end{array}$ & \multicolumn{4}{|c|}{$<0,25 \mathrm{MO} /$ мл } \\
\hline \begin{tabular}{|l|} 
Мікробіологіч- \\
на чистота \\
\end{tabular} & 100 КУО/мЛ & 10 КУО/100 мЛ & 10 КУО/100 мл & $100 \mathrm{KУO} / \Gamma$ & $<100$ КУО/мл \\
\hline \begin{tabular}{|l|} 
Загальний орга- \\
нічний вуглець
\end{tabular} & $\leq 0,5 \mathrm{M \Gamma} / л$ & $\leq 0,5 \mathrm{M \Gamma} / \mathrm{л}$ & $\leq 0,5 \mathrm{мг} / л$ & - & - \\
\hline \begin{tabular}{|l|} 
Питома \\
електропровід- \\
ність, \\
\end{tabular} & \multicolumn{3}{|c|}{ Субстанція має витримувати випробування згідно з методикою } & - & - \\
\hline Важкі метали & $\begin{array}{l}\leq 0,00001 \% \\
(0,1 \mathrm{ppm})\end{array}$ & - & - & $\begin{array}{l}\leq 0,1 \mathrm{ppm} \\
(0,1 \mathrm{мг/л)} \\
\end{array}$ & - \\
\hline Загальний хлор & - & - & - & $\begin{array}{l}0,1 \mathrm{ppm} \\
(0,1 \mathrm{мг/л)} \\
\end{array}$ & $\leq 0,1 \mathrm{M \Gamma} / \Omega$ \\
\hline \begin{tabular}{|l|} 
Нітрати (у \\
перерахунку на \\
азот)
\end{tabular} & - & $\begin{array}{l}\leq 0,00002 \% \\
(0,2 \mathrm{ppm})\end{array}$ & $\begin{array}{l}\leq 0,00002 \% \\
(0,2 \mathrm{ppm})\end{array}$ & $\begin{array}{l}\leq 2 \mathrm{ppm} \\
(2 \mathrm{мг/л)}\end{array}$ & $\leq 2 \mathrm{мг} / л$ \\
\hline Сульфати & - & - & - & $\begin{array}{l}\leq 50 \mathrm{ppm} \\
(50 \mathrm{M \Gamma} / \text { л) }\end{array}$ & $\leq 100 \mathrm{Mг} /$ Л \\
\hline Хлориди & - & - & - & $\begin{array}{l}\leq 50 \mathrm{ppm} \\
(50 \mathrm{M \Gamma} / \text { л) }\end{array}$ & - \\
\hline Фториди & - & - & - & - & $\leq 0,2 \mathrm{M \Gamma} / л$ \\
\hline Аміак & - & - & - & $\begin{array}{l}\leq 0,2 \mathrm{ppm} \\
(0,2 \text { мГ/л) }\end{array}$ & - \\
\hline Цинк & - & - & - & $\begin{array}{l}\leq 0,1 \mathrm{ppm} \\
(0,1 \mathrm{мг} / \mathrm{\pi})\end{array}$ & $\leq 0,1 \mathrm{M \Gamma} / л$ \\
\hline \begin{tabular}{|l|} 
Алюміній \\
(якщо субстан- \\
ція призначена \\
для виробни- \\
цтва розчинів \\
для діалізу)
\end{tabular} & $\begin{array}{l}\leq 0,000001 \% \\
(10 \mathrm{ppb})\end{array}$ & $\begin{array}{l}\leq 0,000001 \% \\
(10 \mathrm{ppb})\end{array}$ & $\begin{array}{l}\leq 0,000001 \% \\
(10 \mathrm{ppb})\end{array}$ & $\leq 10$ мкг/л & $\leq 0,01 \mathrm{Mг} / л$ \\
\hline Кальцій & - & - & - & $\begin{array}{l}\leq 2 \mathrm{ppm} \\
(2 \mathrm{M \Gamma} / \mathrm{\pi}) \\
\end{array}$ & \begin{tabular}{|l}
$\leq 2$ мг/л \\
$(0,05$ ммоль/л)
\end{tabular} \\
\hline Магній & - & - & - & $\begin{array}{l}\leq 2 \mathrm{ppm} \\
(2 \mathrm{M \Gamma} / \mathrm{\pi})\end{array}$ & $\begin{array}{l}\leq 4 \text { мг/л } \\
(0,15 \text { ммоль/л) }\end{array}$ \\
\hline Калій & - & - & - & $\begin{array}{l}\leq 2 \mathrm{ppm} \\
(2 \mathrm{M \Gamma} / \pi)\end{array}$ & $\begin{array}{l}\leq 8 \text { мг/л } \\
(0,2 \text { ммоль/л) }\end{array}$ \\
\hline Натрій & - & - & - & $\begin{array}{l}\leq 50 \mathrm{ppm} \\
(50 \mathrm{Mг} / \text { л) }\end{array}$ & \begin{tabular}{|l|}
$\leq 70$ мг/л \\
(3 ммоль/л)
\end{tabular} \\
\hline Мідь & - & - & - & - & $\leq 0,1 \mathrm{мг} / л$ \\
\hline Стибій & - & - & - & - & $\leq 0,006 \mathrm{мг} / л$ \\
\hline Арсен & - & - & - & - & $\leq 0,005 \mathrm{Mг} /$ л \\
\hline Барій & - & - & - & - & $\leq 0,1 \mathrm{мг} / л$ \\
\hline
\end{tabular}


Продовження табл. 2

\begin{tabular}{|c|c|c|c|c|c|}
\hline \multicolumn{6}{|c|}{ Показники якості води } \\
\hline Берилій & - & - & - & - & $\leq 0,0004$ \\
\hline Кадмій & - & - & - & - & $\leq 0,001 \mathrm{мг} / л$ \\
\hline Хром & - & - & - & - & $\leq 0,014$ мг/л \\
\hline Ртуть & - & - & - & $\begin{array}{l}\leq 0,001 \mathrm{ppm} \\
(0,001 \mathrm{M \Gamma} / \pi)\end{array}$ & $\leq 0,0002 \mathrm{Mг} / \Omega$ \\
\hline Селен & - & - & - & - & $\leq 0,09 \mathrm{M \Gamma} / л$ \\
\hline Срібло & - & - & - & - & $\leq 0,005$ мг/л \\
\hline
\end{tabular}

Таким чином, вода для приготування концентратів має відповідати ще і низці показників Свропейської фармакопеї та ISO 23500-3, окрім вимог ДФУ. Однак, варто зауважити, що вимоги Європейської фармакопеї стосовно деяких показників (вмісту магнію, калію, натрію, ртуті) є жорсткішими. Загалом можна зробити висновок, що відносно якості води є розбіжності в нормативно-технічних документах. Окрім цього, показники якості визначаються категорією обраної води для виробництва концентратів для ГД. Відповідно до ДФУ вміст мікроорганізмів подано як підхожу межу, що вимагає вживання заходів, а в ISO зазначено, що за умови досягнення 50\% від максимально допустимого рівня мікроорганізмів або бактеріальних ендотоксинів у воді необхідно здійснювати коригувальні дії $[8,12]$.

Відповідно до чинних нормативних документів немає вимоги випробовувати кислотні концентрати на ріст бактерій $[2,4,7]$. Це можна пояснити тим, що рідкі кислотні концентрати через високу осмолярність і низьке значення показника $\mathrm{pH} \mathrm{\epsilon}$ несприятливим середовищем для життєдіяльності більшості мікроорганізмів $[5,15]$. Водночас відомо багато мікроорганізмів-екстремофілів, які потребують або можуть пристосуватися до специфічних умов: ацидофіли - до кислого значення $\mathrm{pH}(0-5)$, галофіли - до концентрації солей до $30 \%$, осмофіли - до високого осмотичного тиску. Високий осмотичний тиск середовища не перешкоджає росту багатьох цвілевих грибів родів Aspergillus i Penicillium, а також деяких видів дріжджів [15]. Тому одним із наших досліджень було вивчення виживання мікроорганізмів у кислотних концентратах, величина $\mathrm{pH}$ яких є близько 3,0 . На основі результатів виконаних досліджень встановлено, що кислотний концентрат відповідає критерію А лише щодо оцінки протибактеріальної активності, а у разі оцінки протигрибкової активності - за критерієм Б, оскільки на 7 добу величина $\lg$ зменшення мікроорганізмів становила 1,63 за вимоги 2. Тому для гарантії належної якості діалізного розчину необхідно забезпечити високий рівень організації виробництва концентратів для ГД [16].

Незважаючи на те, що відповідно до нормативних документів концентрати для ГД можуть бути не стерильними, вищевикладена інформація обгрунтовує необхідність виготовляти ці концентрати у класифікованих виробничих приміщеннях.

Відповідно до обов’язкового додатку 1 «Виробництво стерильних лікарських засобів» настанови з Належної виробничої практики продукцію, що не підлягає кінцевій стерилізації, необхідно готувати й фасувати в приміщенні класу А для асептичних умов, або готувати в приміщенні класу С за наявності ультрафільтрації. Роботи 3 пакувальними матеріалами після миття необхідно здійснювати у приміщенні класу D [17]. Отже, ультрафільтрація дає змогу понизити клас чистоти повітря у виробничому приміщенні.

На сьогодні в усьому світі помітна тенденція до обмеження об' $є м у$ приміщень 3 очищеним повітрям. Зменшення об’єму очищення не тільки підвищує якість обробленого повітря, але є найбільш доцільним з економічної точки зору. Оскільки оптимальною формою випуску концентратів для ГД є полімерні каністри об'ємом 5 л, це унеможливлює їх стерилізацію фізичними чи хімічними методами. Водночас за- 
стосування ультрафільтрів із розміром пор 0,22 мкм (стерилізуюча фільтрація) дасть змогу готувати концентрати у виробничих приміщеннях класу $\mathrm{C}$ повітряного середовища, що забезпечить достатньо низький рівень ризику контамінації частками $\mathrm{i}$ мікроорганізмами, який підходить для фільтрації та стерилізації [17]. Концентрати фільтрують і фасують у приміщенні класу А. Перед стерилізуючою фільтрацією (ультратонкою), після приготування розчину доцільно здійснити попереднє (тонке) фільтрування з метою збільшення тривалості функціонування стерилізуючих фільтрів.

Стерилізація ультратонким фільтруванням дає змогу очистити розчини від будьяких механічних частинок і мікроорганізмів, а для термолабільних засобів цей метод залишається єдино можливим методом стерилізації. Для такого фільтрування використовують установки, до складу яких входять ємкість із розчином, тримач мембранного фільтра, ємкість для фільтрату і джерело надлишкового тиску. Якість фільтрування оцінюють мікробіологічним методом, а саме прямим посівом проби фільтрату на поживні середовища [18]. Вважаємо, що ультратонка фільтрація поряд з асептичними умовами виготовлення (виробництво в класифікованих приміщеннях) дасть змогу одержувати кислотні концентрати щонайменше з низьким рівнем мікробіологічного забруднення.

Полімерні контейнери й закупорювальні елементи перед наповненням необхідно готувати у навколишньому середовищі класу D і на кінцевому етапі підготовки промивати водою такої самої якості, що й для приготування концентратів.

Газову стерилізацію контейнерів застосовувати недоцільно, зважаючи на значну токсичність цього методу і необхідність тривалої дегазації. Для стерилізації великих контейнерів $є$ ризик залишкових кількостей етиленоксиду, що може негативно впливати на пацієнта [19].

Управління ризиками є невід'ємним елементом системи якості фармацевтичних підприємств, включно з безпекою у виробництві $[20,21]$. Розвиток фармацевтичної промисловості спричинює низку екологічних ризиків, які потрібно мінімізувати 3 метою зменшення негативного впливу на навколишнє середовище [22]. Також розроблення, виробництво й медичне застосування будь-якого лікарського засобу пов'язано з певними ризиками як для навколишнього середовища, так і для працівників фармацевтичного підприємства та пацієнтів [23, 24].

Водночас в Україні рівень екологічної безпеки під час виробництва й використання фармацевтичної продукції $є$ незадовільним і вимагає вирішення [24], оскільки на кожному етапі ії життєвого циклу існують реальні й потенційні екологічні ризики. Тому актуальними є дослідження з планування, мінімізації, перероблення, поводження, зберігання й транспортування відходів виробництва концентратів для ГД.

Екологічна небезпека фармацевтичної продукції полягає в неконтрольованому потраплянні її в довкілля, відсутності технологій очистки стічних вод від її залишків, негативному впливові на природні компоненти навіть у низьких концентраціях, непрогнозованості наслідків для живих організмів. Окрім того, більшість ЛЗ є біологічно активними синтетичними сполуками, аналоги яких відсутні у природі, а під час контакту з іншими активними фармацевтичними інгредієнтами можуть створювати синергічну i/aбо кумулятивну дію $[22,25]$.

Важливо під час фармацевтичного розроблення кислотних концентратів і їх подальшого промислового виробництва представити характеристику профілю небезпеки кислотних концентратів як джерела ФВ, узагальнити інформацію про ФВ виробництва кислотних концентратів, спрогнозувати екологічні ризики, опрацювати заходи зі зниження екологічних ризиків, розширити обізнаність споживачів про поводження з кислотними концентратами як джерелом ФВ. 
Наведемо визначення основних термінів деяких дослідників із питань ризикології та екологічної безпеки у промисловому виробництві.

Так, за Кузьминою А. В., ризик - імовірність певної негативної події, що може відбутись у певний час або за певних обставин по відношенню до деякого контингенту людей, країни, міста тощо. До екологічних ризиків ця авторка відносить екологічні ризики підприємницької діяльності [26]. За Березіною С. Б., ризики - це явища чи події, ймовірне чи передбачене настання яких призведе чи може призвести до негативних наслідків [27]. За Кордеро Г. А. і співавт. ризик - це вірогідність виникнення несприятливої ситуації або невдалий результат будь-якого процесу. Термін «ризик» не завжди, але зазвичай свідчить про щось негативне [24].

Оцінку ризиків можна використовувати для кількісної оцінки впливу довкілля на здоров'я населення; встановлення стандартів; поточного й запобіжного санітарного контролю; розроблення заходів для мінімізації ризиків. Це є корисним інструментом для прийняття рішень для мінімізації ризиків [27, 28].

Керування ризиком є логічним продовженням оцінки ризику і спрямоване на обгрунтування найкращих у певній ситуації рішень із мінімізації або зведення до нуля ризику, а також динамічного контролю експозицій ризиків, оцінювання ефективності й коригування заходів, направлених на мінімізацію ризиків. Для визначення екологічних ризиків під час промислового виробництва рідких кислотних концентратів необхідно врахувати, які саме чинники формуватимуть рівень екологічної безпеки і можуть призвести до виникнення ситуації з відповідними негативними наслідками для навколишнього середовища й людини [26-28].

Стандарти Міжнародної організації зі стандартизації (ISO, серія 9000) орієнтують усі організації на застосування ризик-орієнтованого мислення для прийняття будь-яких управлінських рішень, що можуть впливати на відповідність товарів і послуг встановленим вимогам [20].

За визначенням ВООЗ до ФВ відносять ЛЗ, що не відповідають вимогам якості або медичним стандартам [29]. Але автори Вовк О. О. і Бойченко М. С. наводять більш конкретне визначення: фармацевтичні відходи - це відходи лікувально-профілактичних закладів у формі матеріалів, речовин, виробів, які втратили частково чи повністю свої первинні споживчі властивості під час здійснення медичних маніпуляцій, виконуваних у процесі лікування або обстеження людей у медичних закладах, а також відходи аптек і фармацевтичних виробництв [23].

На нашу думку, саме під час серійного виробництва фармацевтичної продукції об'єм ФВ може бути найбільшим. Для встановлення ризиків у промисловому фармацевтичному виробництві необхідно визначити профіль ФВ. За профілем небезпеки для зовнішнього середовища - відходи кислотних концентратів є відходами фармацевтичної промисловості, за агрегатним станом є рідиною - сумішшю солей у високій концентрації, які спричинятимуть суттєве підвищення мінералізації стічних вод у разі потрапляння в них без відповідного розведення.

У процесі опрацювання складу й технології концентратів для ГД є залишки лабораторних серій, зразки для арбітражного зберігання й вивчення стабільності, а під час серійного промислового виробництва - залишки неякісної, нереалізованої, протермінованої або повернутої продукції, включно з протермінованими лікарськими й допоміжними речовинами, зразки для арбітражного зберігання тощо.

Для запобігання несанкціонованому скиданню й розміщенню відходів, що може створювати небезпеку для навколишнього природного середовища і здоров'я людини, прийнято Закону України «Про забезпечення санітарного та епідемічного благополуччя населення». Відповідно до цього закону, підприємства зобов'язані утримувати надані в користування чи належні їм на праві власності земельні ділянки і території згідно зі санітарними нормами. 
На рисунку автори надали схему ФВ, що утворюються під час фармацевтичного розроблення, промислового виробництва і медичного застосування кислотних розчинів для ГД.

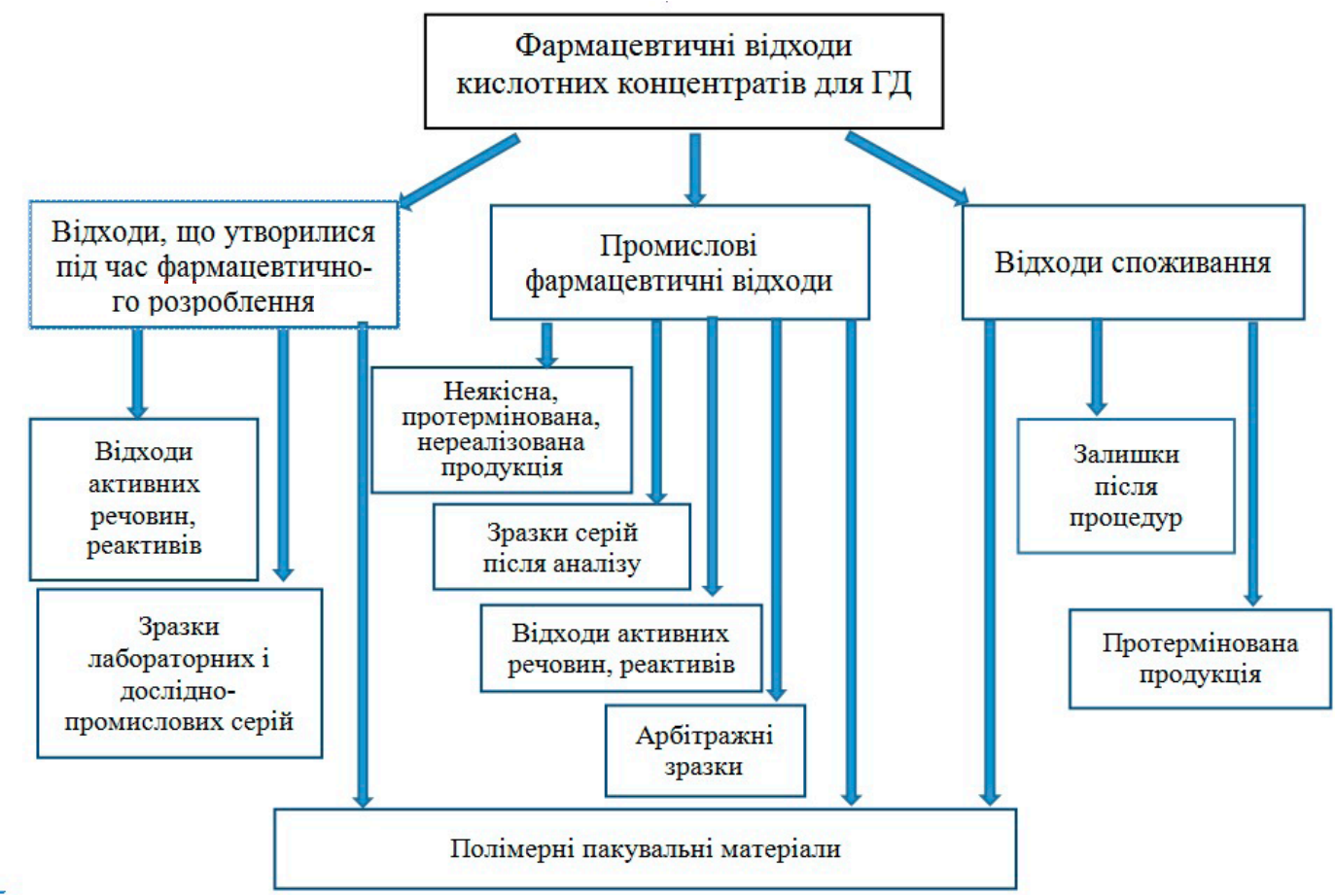

\section{Рис. Фармацевтичні відходи, що утворилися під час фармацевтичного розроблення, промислового виробництва і медичного застосування кислотних розчинів для гемодіалізу}

На підставі вищевикладеного, під час досліджень розробки ЛЗ необхідно виконувати не тільки дослідження, пов'язані з розробленням складу й технології, а здійснювати аналіз небезпеки, яку може спричинити продукція, яку планують впроваджувати в серійне виробництво, вивчають токсикологічні і фізико-хімічні властивості компонентів продукту і самого продукту, опрацьовують заходи для мінімізації ризику, план на випадок надзвичайних ситуацій тощо. У процесі трансферу технології розробляють план аудиту екологічної безпеки підприємства. Тому ми аналізували головні екологічні ризики, пов'язані з розробленням і впровадженням у серійне виробництво кислотних концентратів для ГД, опрацьовували характеристики профілю небезпеки цих концентратів як джерела ФВ.

Аналіз екологічного ризику - це систематичне використання інформації про ризик, порівняння його з прийнятним ризиком, обгрунтування раціональних заходів захисту $[25,26]$.

Ризики поділяють на реальні і потенційні. Ризик реальний - це ймовірність деякої негативної події, зумовленої наявністю реального, безперервного або періодично активного шкідливого чинника. Водночас потенційний ризик - це ймовірність деякої негативної події, зумовленої наявністю потенційного чинника [26]. Серед реальних ризиків ми розглядаємо наявність залишків лабораторних і дослідно-промислових серій на підприємстві, арбітражні зразки промислових серій, зразки промислових серій після аналізу тощо. До потенційних ризиків ми віднесли протерміновані лікарські речовини, неякісну, нереалізовану, протерміновану або повернуту продукцію, продукцію з пошкодженою упаковкою, зокрема під час транспортування (табл. 3). 
Екологічні ризики і їх зменшення у виробництві кислотних концентратів для гемодіалізу

\begin{tabular}{|c|c|}
\hline Ризики & Шляхи зменшення ризику \\
\hline \multicolumn{2}{|r|}{ Потенційні } \\
\hline $\begin{array}{l}\text { Протерміновані лікарські й допоміжні } \\
\text { речовини }\end{array}$ & $\begin{array}{l}\text { Включення в стандарт «Принципи дистрибуції» положення } \\
\text { про оборотність серій; опрацювання заходів із використання } \\
\text { реактивів в інших галузях народного господарства }\end{array}$ \\
\hline Неякісна продукція & $\begin{array}{l}\text { Опрацювання заходів відповідно до вимог належної ви- } \\
\text { робничої практики для зведення до мінімуму виробництва } \\
\text { неякісної продукції }\end{array}$ \\
\hline Нереалізована продукція & \multirow{2}{*}{$\begin{array}{l}\text { Включення в стандарт «Принципи дистрибуції» положення } \\
\text { про оборотність серій }\end{array}$} \\
\hline Протермінована продукція & \\
\hline Повернута продукція & $\begin{array}{l}\text { Опрацювання заходів щодо прийняття рішень стосовно по- } \\
\text { вернутої продукції }\end{array}$ \\
\hline \multicolumn{2}{|r|}{ Реальні } \\
\hline $\begin{array}{l}\text { Залишки лабораторних і дослідно- } \\
\text { промислових серій на підприємстві }\end{array}$ & Зменшення кількості контейнерів у цих серіях \\
\hline Арбітражні зразки промислових серій & $\begin{array}{l}\text { Зменшення їх кількості, що породжує ризик невідповідності } \\
\text { готової продукції вимогам МКЯ як під час випуску, так і під } \\
\text { час розгляду рекламацій }\end{array}$ \\
\hline $\begin{array}{l}\text { Зразки промислових серій після } \\
\text { аналізу тощо }\end{array}$ & $\begin{array}{l}\text { Розведення водою з наступним контролем вмісту хлоридів } \\
\text { у стічних водах; опрацювання заходів із використання від- } \\
\text { ходів для переробки }\end{array}$ \\
\hline Промивні води обладнання & Контроль вмісту хлоридів у стічних водах \\
\hline
\end{tabular}

Оскільки ризик вважають прогностичною категорією [27], то необхідно прогнозувати як ризики, так і їх мінімізацію. Зараз розглядають дві концепції зменшення екологічних ризиків. Відповідно до першої концепції ризики необхідно знижувати, мінімізуючи саме небезпечне явище, зокрема і техногенне навантаження на природне середовище, виконуючи для цього технічні засоби і заходи щодо охорони природи. Другу концепцію пов'язують зі зменшенням екологічного ризику шляхом оптимізації соціально-економічних умов і таким чином підвищення стійкості населення до цього ризику [26].

За головною парадигмою теорії ризиків уникнення одного ризику породжує виникнення іншого. Таким чином, зменшення кількості арбітражних зразків породить ризик неприйняття адекватного рішення в разі забракування серії за якимось показником, тобто може виникнути ситуація, коли буде недостатньо зразків для переконтролю i, отже, прийняття рішення.

Запропоновано стадії управління ризиками щодо ФВ під час виробництва кислотних концентратів ГД:

• визначення профілю небезпеки кислотних концентратів для навколишнього середовища;

• виявлення ризиків, а також поповнення знань про профіль небезпеки;

- планування й впровадження заходів із мінімізації ризиків;

- а також оцінка ефективності цих заходів із зниження ризиків.

Відповідно до першої концепції зниження ризиків, на підприємстві має бути розроблено заходи для запобігання виникненню потенційних ризиків: наявність протермінованої чи неякісної продукції, а також заходи для зменшення небезпеки від реальних ризиків.

Основна проблема ФВ рідких кислотних концентратів для ГД пов'язана 3 мінералізацію природних і стічних вод у зв'язку з можливим потраплянням великої 
кількості хлоридів у стічні води і міську каналізаційну мережу або зливну каналізацію. Численні дослідження свідчать про несприятливий вплив на водні об'єкти Л3, які потравляють у них разом зі стічними водами [23, 27, 30, 31]. ФВ негативно впливають на екосистеми, потрапляючи у навколишнє середовище й стічні води [30]. Інші автори зазначають, що саме скид промислових стічних вод і високомінералізованих шахтних вод зумовлює зростання вмісту солей у водоймах промислових регіонів східної, південної та центральної України. Тому проблема зменшення мінералізації природних і стічних вод, переробка відпрацьованих розчинів iз високим вмістом солей є актуальною екологічною проблемою сьогодення [32].

Відповідно до Водного кодексу України, вторинні водокористувачі скидають стічні води у водні об'єкти на підставі дозволів на спеціальне водокористування. Однак вони не мають скидати у стічні води промислову сировину, реагенти, напівпродукти й кінцеві продукти в кількості, яка перевищує встановлені нормативи технологічних відходів. Згідно з Правилами приймання стічних вод, до систем централізованого водовідведення для безпечного їх відведення й очищення на каналізаційних очисних спорудах, максимально допустиме значення вмісту хлоридів $\left(\mathrm{Cl}^{-}\right)$i/aбо концентрація в пробі стічних вод становить $350 \mathrm{Mг} /$ дм $^{3}$, а показник $\mathrm{pH}$ середовища має знаходитися в межах 6,5-9,0 [33].

Згідно з наказом МО3 України від 24. 04. 2015 № 242 «Про затвердження Правил утилізації та знищення лікарських засобів», знешкодження відходів ЛЗ - це зменшення чи усунення небезпечності відходів ЛЗ шляхом механічного, фізико-хімічного чи біологічного оброблення. Але в наказі не зазначено конкретні методи [34].

Для зменшення навантаження на природне середовище, зокрема на стічні води, актуальним $є$ опрацювання методик із розведення концентратів водою. Ми опрацювали методику усунення небезпечності відходів кислотних концентратів шляхом фізико-хімічного оброблення, а саме розведення їх водою для приведення концентрації хлоридів до максимально допустимого значення їх вмісту в стічних водах:

$$
\begin{gathered}
3605 \text { ммоль } / л \times 35,5 \text { г/моль : } 1000=128 \text { г/л, } \\
128 \text { г/л : 0,35 г/л = } 366 \text { л води. }
\end{gathered}
$$

Таким чином, для приведення вмісту хлоридів до максимально допустимого значення їх вмісту в стічних водах необхідно 1 л концентрату розвести до 366 л. Також підприємство має періодично вимірювати показник $\mathrm{pH}$ стічних вод, зважаючи на оцтову кислоту в складі концентратів. За величин, менших за 6,5, необхідно разом із розведенням нейтралізувати $1 \mathrm{M}$ розчином натрію гідроксиду. За відсутності можливості використання води у таких кількостях підприємству необхідно укласти угоди 3 організаціями, які мають ліцензію на переробку відходів.

Одним із можливих заходів зменшення негативної дії потенційних і реальних ризиків є переробка відходів кислотних концентратів із метою одержання інших продуктів. Зокрема, після електролізу протермінованих кислотних концентратів, що містить хлориди натрію, калію, кальцію, магнію, в електролізері можна одержати суміш розчину лугів (натрію гідроксиду, калію гідроксиду і кальцію гідроксиду), магнію гідроксиду і активний хлор, який виділяється у вигляді газу. Хлор можна поглинати лугом або суспензією вапна з одержанням натрію або кальцію гіпохлориту, який в подальшому можна використовувати для знезараження води [32].

\section{В и с н о в к и}

1. Опрацьовано підходи до розроблення технології промислового виробництва кислотних концентратів, зокрема, узагальнено вимоги різних нормативно-технічних документів до води для виробництва, запропоновано класи чистоти виробничих приміщень для підготовки контейнерів, приготування, фільтрування і фасування розчину. 
2. Представлено схему фармацевтичних відходів кислотних концентратів, які утворюються під час фармацевтичного розроблення, промислового виробництва й медичного застосування, та подано профіль їх небезпеки.

3. Наведено потенційні й реальні екологічні ризики у разі виробництва кислотних концентратів для гемодіалізу і шляхи їх мінімізації. Опрацьовано методики усунення небезпеки фармацевтичних відходів кислотних концентратів (розведення водою або електроліз для одержання вторинних продуктів).

\section{С пи сок використаної літе ратури}

1. Лісовий В. М., Андон'єва Н. М., Лісова Г. В. та ін. Хронічна ниркова недостатність: метод. вказ. для студентів та лікарів-інтернів. - Харків: ХНМУ, 2018. - 24 с.

2. European Pharmacopoeia, 8-th ed., Council of Europe. European Directorate for the Quality of Medicines and Health Care (EDQM). 2014: 3656.

3. Державний реєстр медичної техніки та виробів медичного призначення. - Режим доступу: https:// www.dls.gov.ua/print-article/?pa $=335$

4. ISO 23500-4:2019 «Preparation and quality management of fluids for haemodialysis and related therapies - Part 4: Concentrates for haemodialysis and related therapies». URL: https://www.iso.org/obp/ ui/\#iso:std:iso:23500:-4:ed-1:v1:en

5. Філіпська А. М. Гудзь Н. І. Розробка методик контролю якості концентратів для гемодіалізу / Зб. наук. праць співроб. НМАПО імені П. Л. Шупика. - К., 2016. - Вип. 25, Книга 1. - С. 569-575.

6. Montanari L. B., Sartori F. G., Cardoso M. J. O. et al. Microbiological contamination of a hemodialysis center water distribution system // Rev. Inst. Med. Trop. S. Paulo. - 2009. - V. 51, N 1. - P. 37-43. https://doi. org/10.1590/S0036-46652009000100007

7. Nystard R. Microbiology of Water and Fluids for Hemodialysis // J. Chin. Med. Assoc. - 2008. - V. 71, N 5. - P. 223-229. https://doi:10.1016/S1726-4901(08)70110-2

8. ISO 23500-3:2019 «Preparation and quality management of fluids for haemodialysis and related therapies - Part 3: Water for haemodialysis and related therapies». URL: https://www.iso.org/standard/67612.html

9. Edalat-nejad M., Ghasemikhah R., Delavar M. Aluminum overload: still as a source of concern in hemodialysis patients // Saudi J. Kidney Diseases and Transplantation. - 2014. - V. 25, N 2. - P. 412-414. https://doi.org/10.4103/1319-2442.128602

10. Tsai M. H., Fang Y. W., Liou H. H. et al. Association of serum aluminum levels with mortality in patients on chronic hemodialysis // Sci. Reports. - 2018. - V. 8. - Article number: 16729. https://doi.org/10.1038/ s41598-018-34799-5

11. Державна фармакопея України: в 3 т. / ДП «Український науково-експертний фармакопейний центр якості лікарських засобів». 2-е вид. - Харків: ДП «Український науково-експертний фармакопейний центр якості лікарських засобів», 2015. - Т. 1. - 1128 с.

12. Державна фармакопея України: в 3 т. / ДП «Український науково-експертний фармакопейний центр якості лікарських засобів». 2-е вид. -Харків: ДП «Український науково-експертний фармакопейний центр якості лікарських засобів», 2014. - Т. 2. - 724 с.

13. Настанова «Лікарські засоби. Якість води для застосування у фармації СТ-Н МОЗУ 42-3.7:2013». - K., 2013. $-32 \mathrm{c}$.

14. Коритнюк Р. С., Давтян Л. Л., Гудзь Н. І. та ін. Медична-біологічна функція води // Фармац. журн. - 2019. - № 3. - С. 65-75. https://doi.org/10.32352/0367-3057.3.19.08

15. Мельничук М. Д., Кляченко О. Л., Бородай В. В. Екологія біологічних систем (екологія мікроорганізмів): навч. посібник. - Вінниця: ТОВ «Нілан-ЛТД», 2014. - 248 с.

16. Корещька А. М., Гудзь Н. І., Ділай Н. В. До питання розробки методики мікробіологічної чистоти концентрованих розчинів для гемодіалізу / Сучасні досягнення фармацевтичної технології і біотехнології: матер. IV наук.-практ. конф. з міжнар. уч., м. Харків, 16-17 жовтня 2014 р. - Харків, 2014. - С. 160.

17. Настанова «Лікарські засоби. Належна виробнича практика. СТ-Н МОЗУ 42-4.0:2020» / Розроб. М. Ляпунов, О. Безугла, Н. Тахтаулова та ін. Вид. офіц. - К.: МОЗ України, Державна служба лікарських засобів, 2020. -338 с.

18. Государственный научный центр лекарственных средств (ГНЦЛС). Госкоммедбиопром. Технология и стандартизация лекарственных средств. Сборник научних трудов. - Харьков: ООО «РИРЕГ», 1996. - $784 \mathrm{c}$.

19. Шевченко В. Порівняльна характеристика методів стерилізації на основі стандартів // PHARMATechExpo J. - 2020. - № 3-4. - С. 83-92. - Режим доступу: https:/uni-cert.ua/wp-content/ uploads/2020/12/Journal_PHTE20_A4_UniCert.pdf

20. Лебединець B. $\bar{O}$., Курінна $\bar{M}$. B. Оцінка ризиків на етапі фармацевтичної розробки лікарського засобу індопрес ретард у таблетованій формі // Управління, економіка та забезпечення якості в фармації. - 2016. - № 4. - С. 11-20. - Режим доступу: http://nbuv.gov.ua/UJRN/Uezyaf_2016_4_4

21. Настанова СТ-Н МОЗУ 42-4.2:2011 «Лікарські засоби. Управління ризиками для якості (ICH Q9)» / Розроб. М. Ляпунов, О. Безугла, О. Соловйов та ін. Вид. офіц. - К.: МОЗ України, Державна служба лікарських засобів, 2011. $-26 \mathrm{c}$.

22. Mudgal S., De Toni A., Lockwood S. et al. Study on the environmental risks of medicinal products. Final Report Executive Agency for Health and Consumers 12 December 2013. - URL: https://ec.europa.eu/ health/sites/default/files/files/environment/study_environment.pdf 
23. Вовк О. О., Бойченко М. С. Причинно-наслідковий аналіз стану екологічної безпеки під час виробництва та використання фармацевтичної продукції // Наукоємні технології. - 2017. - Т. 1, № 33. C. 71-77. - Режим доступу: http://nbuv.gov.ua/UJRN/Nt 2017 1 12

24. Кордеро Г. А., Борщевська М. I, Борщевський Г. I. Зв'язок фармаконагляду лікарських засобів 3 можливими ризиками на етапах їхнього життєвого циклу // Фармац. отрасль. - 2020. - Т. 3, № 80. - C. 98-105. - Режим доступу: https://promoboz.com/journal/2020/3-80-iyun/zv-yazok-farmakonaglyadulikarskih-zasobiv-z-mozhlivimi-rizikami-na-etapah-yihnogo-zhittyevogo-tsiklu/

25. Agerstrand M., Berg C., Björlenius B. et al. Improving environmental risk assessment of human pharmaceuticals // Environ. Sci. Technol. - 2015. - V. 49, N 9. - P. 5336-5345. https://doi.org/10.1021/acs. est.5b00302

26. Кузьмина В. А. Екологічна безпека: Конспект лекцій. - Одеса: Вид-во ТЕС, 2013. - 131 с. Режим доступу: https://learn.ztu.edu.ua/pluginfile.php $/ 57377 / \mathrm{mod}$ resource/content $/ 1 /$ Ekobezpeka_\%D0\%B F\%D1\%96\%D0\%B4\%D1\%80\%D1\%83\%D1\%87\%D0\%BD\%D0\%B8\%D0\%BA.pdf

27. Березіна С. Б. Ризик як важливіша категорія економічної теорії // Науковий погляд: економіка та управління. -2018. - № 1 (59).-C. 136-146.-Режим доступу: http://nbuv.gov.ua/UJRN/vamsue_2018_1_21

28. Верес О. М., Голиш В. М. Дослідження множини ризиків прийняття рішень в галузі екології / Інформаційні системи та мережі: зб. наук. праць. - 2010. - № 2 (689). - С. 67-80. - Режим доступу: http://science.lpnu.ua/uk/sisn/vsi-vypusky/vypusk-689-2010/doslidzhennya-mnozhyny-ryzykiv-pryynyattyarishen-v-galuzi

29. WHO. Health-care waste. URL: https://www.who.int/news-room/fact-sheets/detail/health-care-waste

30. Попович О. Р., Вронська Н. Ю., Ятчишин Ю. Й., Мальований М. С. Проблеми утилізації відходів фармацевтичної галузі (огляд) // Chemistry, Technology and Application of Substances. - 2020. V. 3, N 1. - C. 175-183. - Режим доступу: http://science.lpnu.ua/sites/default/files/journal-paper/2020/ jun/21760/200290himia-maket26.pdf

31. Брезищька Д. М., Гущук I. В. Проблемні питання при поводженні з медичними відходами в Україні // Вісн. соціальної гігієни та організації охорони здоров’я України. - 2019. - Т. 3, № 81. С. 44-50. https://doi.org/10.11603/1681-2786.2019.3.10591

32. Голтвяницька O. В. Видалення та розділення хлоридів і сульфатів при іонообмінному знесоленні води // Східно-Свропейський журн. передових технологій. - 2012. - № 1/6 (55). - С. 40-44.

33. Наказ Міністерства регіонального розвитку, будівництва та житлово-комунального господарства України № 316 від 01. 12. 2017 р. «Про затвердження Правил приймання стічних вод до систем централізованого водовідведення та Порядку визначення розміру плати, що справляється за понаднормативні скиди стічних вод до систем централізованого водовідведення». - Режим доступу: https://zakon. rada.gov.ua/laws/show/z0056-18\#Text

34. Наказ МО3 України № 242 від 24. 04. 2015 р. «Про затвердження Правил утилізації та знищення лікарських засобів». - Режим доступу: https://zakon.rada.gov.ua/laws/show/z0550-15\#Text

\section{Re f e r e n c e s}

1. Lisovyi V. M., Andonieva N. M., Lisova H. V. ta in. Khronichna nyrkova nedostatnist: metod. vkaz. dlia studentiv ta likariv-interniv. - Kharkiv: KhNMU, 2018. - 24 s.

2. European Pharmacopoeia, 8-th ed., Council of Europe. European Directorate for the Quality of Medicines and Health Care (EDQM). 2014: 3656.

3. Derzhavnyi reiestr medychnoi tekhniky ta vyrobiv medychnoho pryznachennia. - Rezhym dostupu: https://www.dls.gov.ua/print-article/?pa=335

4. ISO 23500-4:2019 «Preparation and quality management of fluids for haemodialysis and related therapies - Part 4: Concentrates for haemodialysis and related therapies». URL: https://www.iso.org/obp/ ui/\#iso:std:iso:23500:-4:ed-1:v1:en

5. Filipska A. M. Hudz N. I. Rozrobka metodyk kontroliu yakosti kontsentrativ dlia hemodializu / Zb. nauk. prats spivrob. NMAPO imeni P. L. Shupyka. - Kyiv, 2016. - Vyp. 25, Knyha 1. - S. 569-575.

6. Montanari L. B., Sartori F. G., Cardoso M. J. O. et al. Microbiological contamination of a hemodialysis center water distribution system // Rev. Inst. Med. Trop. S. Paulo. - 2009. - V. 51, N 1. - P. 37-43. https://doi. org/10.1590/S0036-46652009000100007

7. Nystard R. Microbiology of Water and Fluids for Hemodialysis // J. Chin. Med. Assoc. - 2008. - V. 71, N 5. - P. 223-229. https://doi:10.1016/S1726-4901(08)70110-2

8. ISO 23500-3:2019 «Preparation and quality management of fluids for haemodialysis and related therapies - Part 3: Water for haemodialysis and related therapies». URL: https://www.iso.org/standard/67612.html

9. Edalat-nejad M., Ghasemikhah R., Delavar M. Aluminum overload: still as a source of concern in hemodialysis patients // Saudi J. Kidney Diseases and Transplantation. - 2014. - V. 25, N 2. - P. $412-414$. https://doi.org/10.4103/1319-2442.128602

10. Tsai M. H., Fang Y. W., Liou H. H. et al. Association of serum aluminum levels with mortality in patients on chronic hemodialysis // Sci. Reports. - 2018. - V. 8. - Article number: 16729. https://doi.org/10.1038/ s41598-018-34799-5

11. Derzhavna farmakopeia Ukrainy: v 3 t. / DP «Ukrainskyi naukovo-ekspertnyi farmakopeinyi tsentr yakosti likarskykh zasobiv». 2-e vyd. - Kharkiv: DP «Ukrainskyi naukovo-ekspertnyi farmakopeinyi tsentr yakosti likarskykh zasobiv», 2015. - T. 1. - $1128 \mathrm{~s}$.

12. Derzhavna farmakopeia Ukrainy: v 3 t. / DP «Ukrainskyi naukovo-ekspertnyi farmakopeinyi tsentr yakosti likarskykh zasobiv». 2-e vyd. - Kharkiv: DP «Ukrainskyi naukovo-ekspertnyi farmakopeinyi tsentr yakosti likarskykh zasobiv», 2014. - T. 2. -724 s. 
13. Nastanova «Likarski zasoby. Yakist vody dlia zastosuvannia u farmatsii ST-N MOZU 42-3.7:2013». - Kyiv, 2013. -32 s.

14. Korytniuk R. S., Davtian L. L., Hudz N. I. ta in. Medychna-biolohichna funktsiia vody // Farmats. zhurn. - 2019. - № 3. - S. 65-75. https://doi.org/10.32352/0367-3057.3.19.08

15. Melnychuk M. D., Kliachenko O. L., Borodai V. V. Ekolohiia biolohichnykh system (ekolohiia mikroorhanizmiv): navch. posibnyk. - Vinnytsia: TOV «Nilan-LTD», 2014. - 248 s.

16. Koretska A. M., Hudz N. I., Dilai N. V. Do pytannia rozrobky metodyky mikrobiolohichnoi chystoty kontsentrovanykh rozchyniv dlia hemodializu / Suchasni dosiahnennia farmatsevtychnoi tekhnolohii i biotekhnolohii: mater. IV nauk.-prakt. konf. z mizhnar.uch., m. Kharkiv, 16-17 zhovtnia 2014 r. - Kharkiv, 2014. - S. 160 .

17. Nastanova «Likarski zasoby. Nalezhna vyrobnycha praktyka. ST-N MOZU 42-4.0:2020» / Rozrob. M. Liapunov, O. Bezuhla, N. Takhtaulova, ta in. Vyd. ofits. - K.: MOZ Ukrainy, Derzhavna sluzhba likarskykh zasobiv, 2020. - $338 \mathrm{~s}$.

18. Gosudarstvennyj nauchnyj centr lekarstvennyh sredstv (GNCLS). Goskommedbioprom. Tekhnologiya i standartizaciya lekarstvennyh sredstv. Sbornik nauchnih trudov. - Har'kov, OOO «RIREG», 1996. - 784 s.

19. Shevchenko V. Porivnialna kharakterystyka metodiv sterylizatsii na osnovi standartiv // PHARMATechExpo J. - 2020. - № 3-4. - S. 83-92. - Rezhym dostupu: https://uni-cert.ua/wp-content/ uploads/2020/12/Journal_PHTE20_A4_UniCert.pdf

20. Lebedynets V. O., Kurinna $\bar{M} . \bar{V}$. Otsinka ryzykiv na etapi farmatsevtychnoi rozrobky likarskoho zasobu Indopres retard u tabletovanii formi // Upravlinnia, ekonomika ta zabezpechennia yakosti v farmatsii. - 2016. - № 4. - S. 11-20. - Rezhym dostupu: http://nbuv.gov.ua/UJRN/Uezyaf_2016_4_4

21. Nastanova ST-N MOZU 42-4.2:2011 «Likarski zasoby. Upravlinnia ryzykamy dlia yakosti (ICH Q9)» / Rozrob. M. Liapunov, O. Bezuhla, O. Soloviov ta in. Vyd. ofits. - K. : MOZ Ukrainy, Derzhavna sluzhba likarskykh zasobiv, 2011. - $26 \mathrm{~s}$.

22. Mudgal S., De Toni A., Lockwood S. et al. Study on the environmental risks of medicinal products. Final Report Executive Agency for Health and Consumers 12 December 2013. - URL: https://ec.europa.eu/ health/sites/default/files/files/environment/study environment.pdf

23. Vovk O. O., Boichenko M. S. Prychynno-naslidkovyi analiz stanu ekolohichnoi bezpeky pid chas vyrobnytstva ta vykorystannia farmatsevtychnoi produktsii // Naukoiemni tekhnolohii. - 2017. - T. 1, № 33. S. 71-77. - Rezhym dostupu: http://nbuv.gov.ua/UJRN/Nt_2017_1_12

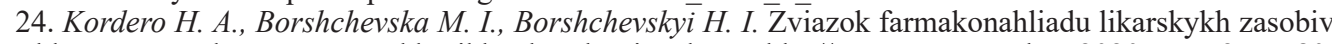
z mozhlyvymy ryzykamy na etapakh yikhnoho zhyttievoho tsyklu // Farmats. otrasl. - 2020. - T. 3, № 80 . - S. 98-105. - Rezhym dostupu: https://promoboz.com/journal/2020/3-80-iyun/zv-yazok-farmakonaglyadulikarskih-zasobiv-z-mozhlivimi-rizikami-na-etapah-yihnogo-zhittyevogo-tsiklu/

25. Agerstrand M., Berg C., Björlenius B. et al. Improving environmental risk assessment of human pharmaceuticals // Environ. Sci. Technol. - 2015. - V. 49, N 9. - P. 5336-5345. https://doi.org/10.1021/acs. est.5b00302

26. Kuzmyna V. A. Ekolohichna bezpeka: Konspekt lektsii. - Odesa: Vyd-vo TES, 2013. - 131 s. - Режим доступу: https://learn.ztu.edu.ua/pluginfile.php/57377/mod_resource/content/1/Ekobezpeka_\%D0\%BF\%D1 $\% 96 \%$ D0\%B4\%D1\%80\%D1\%83\%D1\%87\%D0\%BD\%D0\%B8\%D0\%BA.pdf

27. Berezina S. B. Ryzyk yak vazhlyvisha katehoriia ekonomichnoi teorii // Naukovyi pohliad: ekonomika ta upravlinnia. - 2018. - № 1 (59). - S. 136-146. - Rezhym dostupu: http://nbuv.gov.ua/UJRN/ vamsue 2018121

28. Veres $\bar{O} \cdot \bar{M}$., Holysh V.M. Doslidzhennia mnozhyny ryzykiv pryiniattia rishen v haluzi ekolohii / Informatsiini systemy ta merezhi: zb. nauk. prats. - 2010. - № 2 (689). - S. 67-80. - Rezhym dostupu: http://science.lpnu.ua/uk/ sisn/vsi-vypusky/vypusk-689-2010/doslidzhennya-mnozhyny-ryzykiv-pryynyattya-rishen-v-galuzi

29. WHO. Health-care waste. URL: https://www.who.int/news-room/fact-sheets/detail/health-care-waste

30. Popovych O. R., Vronska N. Yu., Yatchyshyn Yu. Y., Malovanyi M. S. Problemy utylizatsii vidkhodiv farmatsevtychnoi haluzi (ohliad) // Chemistry, Technology and Application of Substances. - 2020. V. 3, N 1. - C. 175-183. - Rezhym dostupu: http://science.lpnu.ua/sites/default/files/journal-paper/2020/ jun/21760/200290himia-maket26.pdf

31. Brezytska D. M., Hushchuk I. V. Problemni pytannia pry povodzhenni z medychnymy vidkhodamy v Ukraini // Visn. sotsialnoi hihiieny ta orhanizatsii okhorony zdorovia Ukrainy. - 2019. - T. 3, № 81. - S. 44-50. https://doi.org/10.11603/1681-2786.2019.3.10591

32. Holtvianytska $O$. V. Vydalennia ta rozdilennia khlorydiv i sulfativ pry ionoobminnomu znesolenni vody // Skhidno-Yevropeiskyi zh. peredovykh tekhnolohii. - 2012. - № 1/6 (55). - S. 40-44.

33. Nakaz Ministerstva rehionalnoho rozvytku, budivnytstva ta zhytlovo-komunalnoho hospodarstva Ukrainy № 316 vid 01. 12. 2017 r. «Pro zatverdzhennia Pravyl pryimannia stichnykh vod do system tsentralizovanoho vodovidvedennia ta Poriadku vyznachennia rozmiru platy, shcho spravliaietsia za ponadnormatyvni skydy stichnykh vod do system tsentralizovanoho vodovidvedennia». - Rezhym dostupu: https://zakon.rada.gov.ua/laws/show/z0056-18\#Text

34. Nakaz MOZ Ukrainy № 242 vid 24. 04. 2015 r. «Pro zatverdzhennia Pravyl utylizatsii ta znyshchennia likarskykh zasobiv». - Rezhym dostupu: https://zakon.rada.gov.ua/laws/show/z0550-15\#Text

Надійшла до редакції 15 травня 2021 р. Прийнято до друку 22 травня 2021 р. 
А. М. Філіпська ${ }^{1}$ (https://orcid.org/0000-0002-5759-1521),

I. О. Власенко ${ }^{2}$ (https://orcid.org/0000-0002-5530-4189),

Н. I. Гудзь ${ }^{1}$ (https://orcid.org/0000-0002-2240-0852)

${ }^{1}$ Львівський національний медичний університет імені Данила Галицького

${ }^{2}$ Національний університет охорони здоров'я Украӥни імені П. Л. Шупика, м. Київ

АСПЕКТИ ПРОМИСЛОВОГО ВИРОБНИЦТВА КОНЦЕНТРАТІВ ДЛЯ ГЕМОДІАЛІЗУ

Ключові слова: кислотні концентрати для гемодіалізу, промислове виробництво, екологічні ризики, фармацевтичні відходи

А Н О Т А Ц І Я

Імпортозалежність фармацевтичного ринку України концентратів для гемодіалізу визначає актуальність їх виробництва. Опрацювання трансферу розробки лікарських засобів у промислове виробництво і відповідно розроблення промислової технології рідких кислотних концентратів для гемодіалізу передбачає масштабування технологічного процесу, організацію міжопераційного контролю, встановлення критичних точок технологічного процесу, а також визначення класів чистоти приміщень для виробництва концентратів і ризиків, у тому числі екологічних.

Метою роботи є опрацювання підходів до розроблення технології промислового виробництва кислотних концентратів для гемодіалізу, визначення ризиків у технологічному процесі й контролі якості, а також аналіз головних екологічних ризиків і розроблення методів їх зниження.

Об'єктом дослідження була нормативно-технічна документація стосовно вимог до концентратів для гемодіалізу, характеристика профілю небезпеки кислотних концентратів як джерела фармацевтичних відходів і узагальнення інформації про них у виробництві кислотних концентратів. Використовували результати власних експериментальних досліджень щодо розроблення концентратів. Під час аналізу інформації застосовували системно-оглядовий метод дослідження й контент-аналіз.

На підставі досліджень опрацьовано підходи до розроблення технології промислового виробництва кислотних концентратів, зокрема узагальнено вимоги різних нормативно-технічних документів до води для виробництва, запропоновано класи чистоти виробничих приміщень для підготовки контейнерів, приготування, фільтрування і фасування розчину. Представлено схему фармацевтичних відходів кислотних концентратів, які утворюються під час фармацевтичного розроблення, промислового виробництва й медичного застосування та подано профіль їх небезпеки. Наведено потенційні й реальні екологічні ризики у виробництві кислотних концентратів для гемодіалізу і шляхи їх мінімізації. Запропоновані стадії управління ризиками щодо фармацевтичних відходів під час виробництва кислотних концентратів для гемодіалізу охоплюють: визначення профілю небезпеки кислотних концентратів для навколишнього середовища; виявлення ризиків, а також поповнення знань про профіль небезпеки; планування й впровадження заходів із мінімізації ризиків, а також оцінка ефективності цих заходів зі зниження ризиків. Опрацьовано методики усунення небезпеки фармацевтичних відходів кислотних концентратів (розведення водою або електроліз для одержання вторинних продуктів).

А. М. Филипская ${ }^{1}$ (https://orcid.org/0000-0002-5759-1521),

И. А. Власенко ${ }^{2}$ (https://orcid.org/0000-0002-5530-4189),

Н. И. Гудзь ${ }^{1}$ (https://orcid.org/0000-0002-2240-0852)

${ }^{1}$ Львовский национальный медицинский университет имени Данила Галицкого

${ }^{2}$ Национальный университет здравоохранения Украины имени П. Л. Шупика, г. Киев

АСПЕКТЫ ПРОМЫШЛЕННОГО ПРОИЗВОДСТВА КОНЦЕНТРАТОВ ДЛЯ ГЕМОДИАЛИЗА

Ключевые слова: кислотные концентраты для гемодиализа, промышленное производство, экологические риски, фармацевтические отходы

А Н Н О Т А ЦИЯ

Импортозависимость фармацевтического рынка Украины концентратов для гемодиализа определяет актуальность их производства. Трансфер разработки лекарственного средства в промышленное производство, и соответственно, разработка промышленной технологии жидких кислотных концентратов для гемодиализа предусматривает масштабирование технологического процесса, организацию межоперационного контроля, установление критических точек технологического процесса, а также определения классов чистоты помещений для производства концентратов и рисков, в том числе экологических.

Целью работы является разработка подходов для создания технологии промышленного производства кислотных концентратов для гемодиализа, определение рисков в технологическом процессе и контроле качества, а также анализ главных экологических рисков и разработка методов их снижения.

Объектом исследования была нормативно-техническая документация относительно требований к концентратам для гемодиализа, характеристика профиля безопасности кислотных концентратов в качестве источника фармацевтических отходов и обобщение информации о них при производстве кислотных концентратов. Учитывали результаты собственных экспериментальных исследований по разработке концентратов. При анализе інформації применяли системно-обзорный метод исследования и контент-анализ.

На основании исследований разработаны подходы для технологии промышленного производства кислотных концентратов для гемодиализа, в частности, обобщены требования различных нормативно- 
технических документов к воде для производства, предложены классы чистоты производственных помещений для подготовки контейнеров, приготовления, фильтрации и фасовки раствора. Представлена схема фармацевтических отходов кислотных концентратов, которые образуются во время фармацевтической разработки, промышленного производства и медицинского применения, и представлены профили их безопасности. Определены потенциальные и реальные экологические риски при производстве кислотных концентратов для гемодиализа и пути их минимизации. Предложенные стадии управления рисками фармацевтических отходов при производстве кислотных концентратов для гемодиализа включают: определение профиля безопасности кислотных концентратов для окружающей среды; выявление рисков, а также пополнение знаний о профиле безопасности; планирование и внедрение мероприятий по минимизации рисков, а также оценка эффективности этих мер для снижения рисков. Разработаны методики устранения опасности фармацевтических отходов кислотных концентратов (разведение водой или электролиз для получения вторичных продуктов).

A. M. Filipska ${ }^{1}$ (https://orcid.org/0000-0002-5759-1521),

I. O. Vlasenko ${ }^{2}$ (https://orcid.org/0000-0002-5530-4189),

N. I. Hudz ${ }^{1}$ (https://orcid.org/0000-0002-2240-0852)

${ }^{1}$ Danylo Halytsky Lviv National Medical University

${ }^{2}$ Shupyk National Healthcare University of Ukraine, Kyiv

ASPECTS OF THE INDUSTRIAL MANUFACTURE OF CONCENTRATES FOR HAEMODIALYSIS

Key words: acid concentrates for hemodialysis, industrial manufacture, environmental risks, pharmaceutical wastes A B S T R A C T

The import dependence of the pharmaceutical market of Ukraine on concentrates for hemodialysis determines the relevance of their manufacture. Elaboration of the transfer of drug development to industrial manufacture and, accordingly, the development of industrial technology of liquid acid concentrates for hemodialysis involves scaling the process, organization of production control, establishing critical points of the production and determining cleanliness classes for concentrates and risks, including ecological ones.

The aim of the work is to develop approaches to the development of technology for industrial manufacture of acid concentrates for hemodialysis, identification of risks in the technological process and quality control, as well as analysis of major ecological risks and development of methods for their reduction.

The object of the study was the regulatory and technical documentation regarding the requirements for hemodialysis concentrates, characterization of the hazard profile of acid concentrates as a source of pharmaceutical wastes and generalization of the information about them in the manufacture of acid concentrates. We used the results of our own experimental research on the development of concentrates. The system-survey method of research and content analysis were used in the analysis.

On the basis of researches, it was to work up the approaches to the development of technology of industrial manufacture of acid concentrates. Requirements of various normative and technical documents for water for the manufacture were generalized, classes of cleanliness of industrial premises for the preparation of containers, preparation, filtering, and packing of solutions are offered. The scheme of pharmaceutical wastes of acid concentrates, which are formed during pharmaceutical development, industrial manufacture, and medical administration, is presented. The profile of their unsafety is given. Potential and real ecological risks in the manufacture of acid concentrates for hemodialysis and ways to minimize them are presented. The proposed stages of risk management for pharmaceutical waste during the manufacture of acid concentrates of hemodialysis include: determining the hazard profile of acid concentrates for the environment; identification of risks, as well as replenishment of knowledge about the hazard profile; planning and implementation of risk minimization measures as well as evaluation of the effectiveness of these risk reduction measures. Methods for eliminating the safety of pharmaceutical wastes of acid hemodialysis concentrates (dilution with water or electrolysis to obtain by-products) have been developed.

\section{Електронна адреса для листування з авторами: natali_gudz@ukr.net}

(Гудзь Н. I.) 